\title{
Niedokończona strategia. Innowacje, imitacja i przyszły język wrocławskiej polityki rozwoju
}

\section{Sens pisania o przyszłości}

Są w wyobraźni, kiedy się ją zaprzęga do myślenia, dwie widownie śledzące bacznie każde posunięcie pióra. Pierwsza z nich chciałaby, żeby wykład był zajmujący. Domaga się świeżości i inspiracji. Druga pragnie, by na pierwszym miejscu stanęła rzetelność. Oczekuje prawdy o świecie lub o człowieku. Pamięć o tych widowniach, ich wyczekiwaniu i machinalnych próbach dogadzania, kiedy się pisze, jest pomocna w ogóle. Natomiast kiedy tematem jest przyszłość Wrocławia, a na widowniach (obu) znajdują się osoby znające miasto dobrze, ba, dużo lepiej, niż piszący świadomość intelektualnej gry, jaka się toczy, staje się krytyczna. Po pierwsze - ze względów ambicjonalnych (oryginalność). Po drugie zaś - i to jest szczególnie interesujące - dlatego że „przyszłość” jest jednym z nielicznych środowisk myślenia, w którym przeciąganie liny między wyobraźnią pisarską a potrzebą zachowania wiarygodności jest na miejscu. Więcej: „przyszłośćc jest kategorią, w której te dwie siły sprawcze - wola i rozum myślącego - są doskonale, bo niepostrzeżenie, przemieszane.

Przyszłość bierze się z dzisiaj; spekulując na jej temat, wgłębiamy się w dziś i w jakimś sensie je imitujemy. Dostrzegając z kolei niedoskonałość naszej pracy, lub przynajmniej tę niedoskonałość przeczuwając, zaczynamy zostawiać miejsce na nieoczekiwane: oceny formułujemy tak, aby między nimi zmieściło się coś, co - choć dziś niewyobrażalne może tekst pozbawić aktualności, zanim jego skład będzie zakończony. Imitacja, jeśli ją pokornie przeżyć rozumowo, oddzielając fakty od naszej woli względem faktów, może prowadzić do intelektualnej innowacji, do nowego rozumienia lub postrzegania. W tym sensie pisanie o przyszłości w jakimś stopniu pomaga przyszłość tworzyć. Lub przynajmniej daje nam retrospektywne przekonanie, że przyszłość widzieliśmy, kiedy wydarzy się, cośmy przeczuwali.

Miasto. Pamięć i Przyszłość 1 (2016) ISSN 2543-621X 
Imitacja i innowacja - postrzeganie i kwestionowanie; rozumowanie i przyjmowanie do wiadomości; wychodzenie od faktów ku nowym lub nienazwanym zjawiskom; planowanie i rezygnowanie z planów - jest to filozoficzny trop, z którego bierze się ten tekst. Ale trop ten jest dziś więcej niż zabawą myślicieli. Jest praktycznym problemem do rozwiązania de facto przez każdą wspólnotę samorządową, która decyduje się na spisanie własnej wizji rozwoju, swojej strategii. Jest także problemem wspólnoty wrocławskiej.

Pisanie o przyszłości jest zgłębianiem tego, jak rozumieć „zmianę” wobec ciągłości, powtarzalności i wynikania. I choćby tym sposobem łączy się ściśle i konkretnie z Wrocławiem jako dziedziną ludzkiego doświadczenia. Bo zarządzanie miastem, w którym materialne wytwory tradycji przeważnie niemieckiej współistnieją z tworami materialnymi kultury polskiej okresu powojennego, w którym życie instytucji bierze się zarówno z DNA komunistycznej administracji, solidarnościowej organizacji, jak i pradawnych intuicji Rzeczpospolitej, zarządzanie miastem, którego w roku 1945 w sensie funkcjonalnym nie było, a które dziś jest jasnym punktem na mapie Polski, rozporządzanie jego przyszłością - to praca na wskroś przegryziona smakiem innowacji i adaptacji, choćby w postaci mitu. Ciągłość mimo pęknięć - proteuszowy walor Wrocławia - ma zaś nazwę, którą zaczerpnąć możemy ze strategii rozwoju Wrocławia z roku 2006 (Strategia - Wrocław w perspektywie 2020 plus): jest to „innowacyjna kultura eksperymentu"1.

Ale po co esej humanistyczny o innowacjach we Wrocławiu? Po co przysłuchiwać się językowi obcemu sprawom modernizacji instytucjonalnej, dalekiemu od żargonu polityki rozwoju? Po co wiązać przy tym ten sposób komunikowania z Wrocławiem właśnie? Przyczyna po temu jest prosta. Chodzi o różnorodność, która jest potrzebna innowacji. Wyrażenie tej myśli znajdziemy w przywołanej Strategii rozwoju Wrocławia:

„INNOWACYJNA KULTURA EKSPERYMENTU WYMAGA WOLNOŚCI I PRAWA DO BŁĘDU (KONTROLOWANEGO). Jej naturalnym wrogiem jest dążenie do perfekcji, zwłaszcza perfekcji uzasadnianej jako dobro samo w sobie. Trzeba ponosić pewne koszty utrzymania różnorodności. Przestrzeń wolności sprawdzoną w gospodarce trzeba sensownie poszerzać na sfery nauki, edukacji, służby zdrowia, a nawet administracji. Potrzebne jest dowartościowanie organicznej i rezerwa wobec industrialnej metafory rozwoju"2.

Dopóki miejscem refleksji rozwojowej jest także wyobraźnia badacza lub eksperta - a jest tak dziś również w dziedzinach uchodzących za oparte na twardej empirii -

1. Uchwała Nr LIV/3250/06 Rady Miejskiej Wrocławia z dnia 6 lipca 2006 roku w sprawie przyjęcia strategii rozwoju Wrocławia Strategia - Wrocław w perspektywie 2020 plus. Opublikowano: Biuletyn Urzędowy RMW z 24 lipca 2006 r. nr 8, poz. 254. Załącznik do uchwały, s. 11, www.uchwaly.um.wroc.pl (dostęp: 1 IX 2016).

2. Ibidem, s. 11. głos, który nie stroni od pojęć tradycyjnych, ma swoje miejsce.
Miasto. Pamięć i Przyszłość 1 (2016) ISSN 2543-621X 
To prawda, że dziś innowacyjność w przeważającej mierze (i na ogół owocnie) roztrząsana jest jako ciąg zarządczo-biznesowych decyzji, motywowanych i dających się objaśnić i projektować w ramach jakiegoś formalnego modelu. Ale rozwój Wrocławia ma także wymiar "organiczny”, którego nośnikiem są ludzie. To tutaj, w przestrzeni ludzkiej wolności, a czasem ludzkiego kaprysu, bije źródło innowacji. Za sprawą człowieka powtarzalność i prawidłowość, zaobserwowane w przeszłości (i dające podstawę dla modeli teoretycznych), rodzą ostatecznie, miast technicznej replikacji, ewolucyjną, organiczną, zmianę.

To właśnie warunki wrocławskiej „kultury eksperymentu” - środowiska sprzyjającemu przełomowości, przejściom nieliniowym, lub inaczej: jakościowym zmianom na lepsze - są w naszym centrum zainteresowania na poniższych stronach. Postępując w rozważaniach uczynimy trzy kroki. Wpierw pochylimy się nad metodą przyjętą dziesięć lat temu przez autorów wrocławskiej Strategii rozwoju Wrocławia. Metoda ta stanowi pomnik pewnej kultury rozporządzania przyszłością, ale i jednocześnie kultury obchodzenia się z teraźniejszością, której uchwycenie i dowartościowanie jest dla nas fundamentalne. Następnie zwrócimy się ku burzliwej dyskusji na temat adekwatności pozytywistycznych modeli planistycznych i zarządczych (dotykając w ogóle oświeceniowej racjonalności), jaka, z bardzo praktycznych powodów, z nową siłą przetacza się na Zachodzie. Dyskusja ta niechybnie dotyka Wrocławia, jako, połowicznej wprawdzie, ale jednak ekspozytury Zachodniego myślenia instytucjonalnego. Krok ten będzie niezmiernie ważny by lepiej dostrzec ogrom wyzwania, przed jakim stoją osoby sprawujące pieczę nad rozwiązaniami polityki, publicznymi instytucjami oraz językiem demokratycznego dialogu na tematy innowacji we Wrocławiu. Całość zamknięta zostanie pytaniami zaczerpniętymi z anegdot wrocławskich, zebranych na mojej własnej drodze pracownika samorządowego (od 2003) i współtwórcy Wrocławskiego Centrum Akademickiego (2008-2015).

\section{Język strategii rozwoju. Kwestia „ryzyka”.}

W części 1.2. Strategii - Wrocław w perspektywie 2020 plus z lipca 2006 czytamy: W KRAJU NARASTAĆ BĘDZIE ROZCZAROWANIE EFEKTAMI MODERNIZACJI PRZEZ IMITACJĘ. Ujawnią się wady kopiowania pozorów nowoczesności, a nie jej istoty i kopiowania zachowań konsumentów dobrobytu zamiast postaw jego twórców. Nastąpi wypalenie wzorców tzw. normalności. Pojawi się zrozumienie, że prawdziwym źródłem przewag konkurencyjnych są rozwiązania innowacyjne ${ }^{3}$.

To nie jedyne założenie, zawarte w dokumencie sprzed dziesięciu lat, które spełniwszy się, nadaje dyskusji

\section{Miasto. Pamięć i Przyszłość 1 (2016) ISSN 2543-621X}

3. Strategia - Wrocław w perspektywie 2020 plus s. 7.

4. Inne założenia, które się spełniły lub właśnie się spełniają, to, między innymi nadejście kontrrewolucji kulturowej oraz nagły zwrot w dyskusji na temat praktycznego rozumienia zasady subsydiarności. Biegun tej dyskusji, symbolizowany przez wizję "coraz ściślejszej Unii", został odwrócony lub przynajmniej zakwestionowany głosem plebiscytu w Wielkiej Brytanii, a w opinii wielu komentatorów politycznych głos ten może zostać wzmocniony w roku 2017 we Francji, Włoszech, Holandii i Niemczech, nie mówiąc o Grecji. 
o rozwoju ton inny, niżby można było wyłapać jeszcze niedawno. Oto nowy rząd RP w swoim programie przedstawionym w styczniu 2016 kładzie akcent na semantyczne rozróżnienie terminów „innowacja” i "imitacja”. Polska ma szukać endogenicznych ${ }^{6}$ przewag konkurencyjnych, ma się odnaleźć w porządku myślenia i działania, którego symbolicznym przejawem są na poziomie wspólnot europejskich strategie S3 (tzw. inteligentne specjalizacje) ${ }^{7}$, ma odrzucić mityczną wiarę w rozwój, którego głównym przejawem jest kopiowanie zachowań konsumenckich podpatrzonych w państwach rozwiniętych. Wątek myślenia o rozwoju wyeksponowany we wrocławskiej strategii roku 2006 stał się centralną osią narracyjną rozmowy na tematy państwowe.

Ale jak tego dokonać? Jak planować działania wspólnoty, które zmierzają w tym kierunku? Potrzebny jest myślowy grunt, zbliżający ludzi tak różnorodnych jak sami wrocławianie, który dla zespołów rozrzuconych po przynajmniej dwóch różnych dekadach będzie dobrym miejscem do uprawiania pomysłów, dających owoce ${ }^{8}$. Można to zapewnić przez takie rozstrzygnięcie:

„Wyróżnić można trzy poziomy zarządzania przyszłością. Każdy z nich ma swój horyzont czasowy, swoją specyfikę, zespół środków oddziaływania na zachodzące

5. Liczne doniesienia prasowe nastąpiły po ogłoszeniu ustanowienia międzyresortowej Rady ds. Innowacji w styczniu 2016 r. Przykład narracji medialnej w tej sprawie, zbudowanej na zestawieniu imitacja-innowacja, może stanowić oparty na depeszach PAP tekst opublikowany W "Gazecie Wyborczej" 11 | 2016, dostępny na stronie: http://wyborcza.biz/biznes/1,147881,19458073,morawiecki-panstwo-ma-wspierac-innowacje.html?disableRedirects=true (dostęp: 30 VIII 2016).

6. Termin zapożyczony z Narodowych Strategicznych Ram Odniesienia z roku 2006, dokumentu stanowiącego w jakimś sensie pierwszą wielką syntezę polityki rozwoju regionalnego po wejściu Polski do Unii Europejskiej. Na bazie tego dokumentu pożytkowano wszystkie środki unijne w latach 2007-2013.

7. Jedną z fundamentalnych przesłanek dla strategii S3 jest spostrzeżenie, że właściwie wszystkie ośrodki europejskie kopiują te same uniwersalne priorytety naukowe, nie sięgając do tradycji przemysłowych, jakie dostępne są im rzeczywiście, na miejscu. Strategia S3 może być w jakimś sensie rozumiana jako próba geolokalizacji abstrakcyjnych w innym przypadku planów innowacyjnych europejskich regionów.

8. W Strategii - Wrocław w perspektywie 2020 plus czytamy na samym wstępie: „Strategia »Wrocław 2020« nie deklaruje priorytetów i nie stara się wyznaczać zadań do wykonania. Koncentruje się na opisaniu pożądanych zmian cywilizacyjnych poprzez wskazanie kierunków, w których Wrocław powinien się zmieniać. Kieruje się w tym rozpoznaniem wyzwań, którym trzeba będzie stawić czoła, i wartości, które należy chronić, umacniać i rozwijać". op. cit., s. 5 i przewidywane procesy. Schema-

tycznie ująć to można następująco:

- Poziom zadaniowy - bliski horyzont czasowy - zarządzanie przez procedury,

- Poziom operacyjny - horyzont średnioterminowy - zarządzanie przez cele,

- Poziom strategiczny - odległy horyzont czasowy - zarządzanie przez wartości.

Z tego rozróżnienia wynika, że zapisy strategii powinny wskazać wartości, do których realizowania należy dążyć w założonej perspektywie i w ramach sensownie wyobrażalnych środków. Ustalenia: co, jak,

Miasto. Pamięć i Przyszłość 1 (2016) ISSN 2543-621X 
kiedy i za ile trzeba zrobić, należą już do operacyjnego i zadaniowego poziomu zarządzania"9.

Rozstrzygnięcie to jest niezmiernie ciekawe. Przede wszystkim zwraca uwagę na rozdźwięk między potrzebami codzienności a naturą strategii: nie można mylić "strategii" z „planowaniem” i „reagowaniem” na dzisiejsze kłopoty. Strategia w jakimś sensie nie należy do bieżącej polityki samorządowej; nie jest przedmową do wieloletniego planu finansowego Wrocławia. Jeżeli trzeba ją gdzieś usytuować, bliżej będzie postulowanej tutaj praktyce strategicznej do pewnej dyscypliny działania, a nawet kultury, skoro w centrum tej praktyki są wartości, a ważnym jej filarem jest umiejętność rezygnowania z aktywizmu politycznego i myślenia życzeniowego.

Dalej rozstrzygnięcie, o którym mowa, zawiera rozwiązanie, wydawałoby się, oczywiste - bo oczywiste jest rozróżnienie różnych perspektyw czasowych, właściwych dla różnych poziomów dyskusji publicznej. Rozróżnienie to wymaga jednak sporej odwagi, ponieważ przyjmując je, autorzy strategii siłą rzeczy odsuwają z planu strategicznego cały szereg politycznych kwestii, ubranych w szatę „konkretnych problemów", motywując tę decyzję tym, że przysłoniłyby one sens posługiwania się kategorią "strategia”.

Wreszcie, pomysł na strategię, zawarty w dokumencie z 2006 r., ciekawi przez to, że wyróżnia się na tle dokumentów strategicznych, definiujących cele, produkty i wskaźniki realizacji. Dlatego można powiedzieć, że dokument, o którym mowa, jest osobliwością polityki samorządowej. A ja dodam: jest przejawem wrocławskiej „kultury eksperymentu”, którą postuluje jako wartość.

Czy wrocławska publiczność jest sposobna do rozmowy na temat strategii rozwoju miasta językiem zaproponowanym dziesięć lat temu? W trwających pracach nad aktualizacją strategii dominują inne założenia metodyczne. Można zatem powiedzieć, że myślenie sprzed dziesięciu lat jest pojedynczym przebłyskiem. Ale czy to ważne dla przyszłości Wrocławia? Śmiem twierdzić, że tak. Utrzymanie instytucjonalnej zdolności do prowadzenia spraw strategicznych idiomem spisanym w roku 2006 uznaję bowiem za ważny prognostyk dla wrocławskiej „kultury eksperymentu”. Nie dlatego, że dyskusje polityczne mogą specjalnie przebudowywać kulturę, wobec której pozostają raczej wtórne ${ }^{10}$, ale dlatego, że zrównując strategię z planowaniem, ryzykujemy we Wrocławiu utratę kontaktu z istotnym nurtem polskiego życia, który choć widziany na ogół jako balast, w dłuższym rozrachunku ma wiele zalet. Rzecz

\section{Miasto. Pamięć i Przyszłość 1 (2016) ISSN 2543-621X}

131
9. Strategia... S. 9.

10. Należy przyznać rację neomarksistom, z Antonio Gramscim na czele: polityczna hegemonia możliwa jest dopiero, kiedy kultura zmieni się na modłę wytyczoną przez aspirującego hegemona. 
jest o osobistym otwarciu na niewiadome, swoistym oportunizmie, deprecjonującym planowanie i związanym mocno z ograniczoną wiarą w instytucje oraz ich oficjalne narracje. Uznanie tej postawy jest kluczowe dla przyszłości. Stawką jest publiczna akceptacja ryzyka.

Spytajmy zatem: czy strategia rozwoju Wrocławia z roku 2006 była anachronizmem, dziś już zapomnianym, zważywszy napór otoczenia politycznego, odnajdującego w dialektyce celów i wskaźników (raczej niż ryzyka i szansy) poczucie stabilności demokratycznej dyskusji? Jest to podstawowe pytanie dla tego wymiaru przyszłości Wrocławia, który rodzi się z oddziaływania instytucji publicznych. Jest to pytanie o to, czy dobrze obstawiamy, rezygnując z przejawów własnej kultury instytucjonalnej, do których można zaliczyć rzeczony dokument strategiczny i jego ekonomię. Czy „transformacja” we Wrocławiu to proces, w którym nieunikniona jest pełna mimikra zachodnich (czytaj: unijnych) instytucji? Czy też „transformacja”, która przecież się jeszcze nie skończyła, to stan, w którym korzystamy z dobrodziejstw Zachodu i własnej kultury instytucjonalnej, jednocześnie obydwie pielęgnując, ceniąc ich niespójność?

Pytania o stosunek władzy publicznej do ryzyka nie dotyczą tylko Wrocławia. Odwrotnie, należą do najbardziej aktualnych pytań w obrębie tradycji, którą z pieczołowitością imitujemy w naszych rządach: tradycji zachodniego oświecenia. I choć wielu świadków w tej sprawie można powołać (a żaden z nich nie zamknie sprawy definitywnym świadectwem), charakter tego wywodu pozwala skupić się na dwóch. Będą to Nassim Nicholas Taleb, jako swoisty antagonista technokratycznej myśli, oraz George Lakoff, jako wybitny i twórczy apologeta polityki „progresywnej”"11. Obaj, choć na różne sposoby, świadczą o tym samym: że język strategii z roku 2006 jest cenny; że jego pielęgnowanie to bardzo ważne zadanie dla spraw publicznych we Wrocławiu. W istocie we fragmencie, który następuje, chodzi nie tyle o przedstawienie i krytykę czyichś poglądów, ale ich własne odczytanie. Jego owocem będzie przede wszystkim lepsze rozumienie sił ścierających się w nas, kiedy zabieramy się do roztrząsania „innowacyjności”. Taki jest mandat „organicznej” metafory rozwoju, w której z Wrocławiem związane może być wszystko to, co zostaje przywłaszczone przez wrocławskiego ducha; wszystko, co zostaje wchłonięte w krwiobieg wrocław-

11. Termin zapożyczony z tradycji amerykańskiej, w znacznej mierze odpowiadający filozofii pozytywistycznej. Chodzi o rządy dowartościowujące sprawstwo władzy publicznej, oparte na daleko idących interwencjach publicznych, z dopuszczeniem koncentracji władzy. Za ojca tej tradycji można uznać, z pewnym uproszczeniem prezydenta USA w latach 1913-1921 Woodrowa Wilsona. Dziś progresywny nurt cechuje też skupienie na ekologii i lewicowych wartościach społecznych. skiej myśli, czym się powodujemy w demokratycznej dyskusji.
Miasto. Pamięć i Przyszłość 1 (2016) ISSN 2543-621X 


\section{Nassim Taleb i George Lakoff: kryzys zachodnich instytucji widziany z dwóch stron}

Nassim Nicholas Taleb należy do najbarwniejszych postaci współczesnej amerykańskiej kategorii pundit, która to kategoria różni się subtelnie od naszego „eksperta” o tyle, że niesie w sobie podtekst, porównujący osobę obdarzoną tym mianem do mędrca w starożytnych Indiach. Taleb to bez wątpienia postać tyleż zajmująca, co drażliwa'², a to za sprawą zadania, jakie podjął, oraz sposobu, w który je wypełnia. Chodzi o straceńcze zamierzenie: obrócić do góry nogami sposób myślenia o ryzyku w odniesieniu do instytucji, rządów i wielkich organizacji; dokonać afirmacji niespodziewanego, wyrzucając do kosza dwudziestowieczną tradycję zarządzania ryzykiem w oparciu o modele (często matematyczne); skupić się na wiedzy intuicyjnej i dostępnej w obiegu danej tradycji kulturowej (najlepiej śródziemnomorskiej), traktując jako drugorzędną wiedzę dostępną w instytucjach wiedzy takich jak uniwersytet. Ten ikonoklastyczny program z pewnością mógłby zostać wyśmiany, gdyby nie trafność spostrzeżeń, na których bazuje Taleb jako jeden z analityków, którzy „przewidzieli” kryzys finansowy roku 2008.

Metafory, do których odwołuje się Taleb, są specyficzne, jak na byłego maklera, analityka a obecnie filozofa przystało. Wnioski, do których dochodzi, przyglądając się zachowaniu systemów, wymagają wręcz ukucia nowych terminów, dających wgląd w zjawisko raczej skryte za tymi obecnie w obiegu ${ }^{13}$. To istotny symptom. Wszak studia nad rozwojem, ewolucją systemów są abstrakcją wśród abstrakcji. Ewolucja daje się poznać jako kategoria, tylko jeśli podniesiemy na poziom wyższy naszą wiedzę z danej dziedziny i przyjrzymy się jej podobieństwom z wiedzą z dziedzin jeszcze innych, tworząc metapoziom, gdzie istnieje system jako taki. Taleba można zrozumieć właśnie dlatego, że uporczywie i na wiele sposobów wskazuje na istnienie takich metatreści, szafując na przemian terminami naukowymi, analogiami lub anegdotami (tutaj: właściwie anegdotami w funkcji mitów, objaśniających tajemnice świata, który nas otacza). Spośród terminów ugruntowanych, opartych na metaforze geometrycznej, przydatnej w projektowaniu trendów na podstawie danych historycznych, najlepiej wyraża sens jego intelektualnego dzieła pojęcie nieliniowości, oznaczające zdarzenie, zmiany, odbiegające od dotychczasowego schematu, a tym samym niedające się przewidzieć ${ }^{14}$.

Taleb kojarzy w swojej teorii dwie rozległe praktyki Zachodu, w które

\section{Miasto. Pamięć i Przyszłość 1 (2016) ISSN 2543-621X}

133
12. Tygodnik "The Economist" w recenzji ksiązki Antifragile napisał:. „Whether you will find Mr Taleb amusing or irritating, you want to read on”. („Jednych bawi, innych mierzi; ale książkę Taleba trudno odłożyć, jak się już zacznie”, tłum. własne), „The Economist" 17 XI 2012.

13. "Antykruchość" jest takim terminem, choć ze względu na fakt, że sam autor posługuje się nim do komentowania sytuacji niebywale różnorodnych - od decyzji lekarskich po inwestycje giełdowe ze szkolnictwem wyższym włącznie - świadczyć może raczej, że mamy do czynienia z toposem lub przynajmniej pojęciowym wehikułem.

14. N. Taleb. Antifragile. Things That Gain from Disorder, New York 2012 (zob. s. 435-445) 
bije z pasją. Po pierwsze, jest to neoliberalny technokratyzm - a właściwie „ułuda” jego pozornej kontroli procesów. Racjonalistyczna projekcja niedoskonałego modelu na rzeczywistość (utożsamianie rzeczy z próbą jej opisu), sugeruje Taleb, jest iluzją ${ }^{15}$. Ta zaś pcha nas w drugą praktykę: unikanie ryzyka. Eliminowanie ryzyka poprzez złożone zabiegi systemowe - usuwa z naszego pola widzenia najważniejsze informacje na temat systemu, którym się zajmujemy. Tkwią one właśnie w jego nieciągłościach i nieliniowościach - w niechcianych wydarzeniach, ograniczeniach, kryzysach. Odwlekając interwencjami kryzys, doprowadzamy do sytuacji, w której nasze zasoby nie pozwalają już na interwencje lub korekty. Wtedy następuje nie kryzys, tylko krach. Tak jest w gospodarce; tak jest w leczeniu, dziś opierającym się nader często na praktyce nadreagowania, która osłabia własną odporność organizmu; tak jest w edukacji, w której racjonalna wiara w abstrakcyjny, gotowy model wiedzy gasi naturalną zdolność ludzką do pozyskiwania informacji przez eksperyment u konkretnego ucznia ${ }^{16}$.

To, co w poglądach Taleba pociągające i niedopuszczalne zarazem to skupienie na fundamentalnym dla kultury zachodniej przekonaniu o wiodącej roli racjonalności. W istocie pozorna nadpobudliwość pisarska Taleba kryje niepośledni sposób dowodzenia: łącząc argumentację ścisłą z argumentacją historyczną i należącą do gatunku przypowieści, Taleb odrzuca reguły gry w przekonywanie zaproponowane przez racjonalizm rządzących światem technokratów i ekspertów. Eklektyzm takiego pisania słusznie można kojarzyć z umysłowością poprzedzającą oświecenie, ale Taleb, bardziej niż zabłąkanym, antycznym monstrum wśród myślicieli, jest myślącym plebejuszem, który wziął na celownik obrzędowość elit: chce wykazać, że technokratyzm, wzięty wszelako z ziarna rozumowości, jest dziś chwastem zagłuszającym rozum praktyczny, odcinającym nas od intuicji i tradycji nurtujących w tak zwanej europejskiej cywilizacji; że jest jarzmem, którym ludzie nieponoszący odpowiedzialności za swoje błędy obarczyli rzesze nieboraków, niemających nic do powiedzenia w coraz większej liczbie spraw, zagarniętych przez racjonalne kapłaństwo i jego lunarny kult modelu matematycznego. Na tym najniższym poziome, na którym wywód Taleba jest po prostu emocjonalnym buntem przeciwko absurdom i niesprawiedliwościom Zachodu, Taleb może

15. Wszelkie podobieństwa z myślą Friedricha von Hayeka są zasadne. Jednak Hayek przemawiał jako ekonomista, lub filozof, dużo bardziej powściągliwie. Taleb natomiast w swojej Antykruchości jest niczym sarmacki dziejopis, szokujący późniejsze gusta tym, że mówi bez ogródek, jak i tym, że exemplum traktuje na równi z argumentem „naukowym”,Ś Z Z ZZetCzasZWSymbolZJestemNie żyjes jeśli chodzi o moc oddziaływania na czytelnika (co jest pewnie słusznym podejściem, ale nie jest też podejściem niezawodnym).

16. op. cit., s. 100-130, 187-201. być widziany jako jeden z trybunów plebejskiej rewolucji, która na różne sposoby i w różnych kostiumach przejawia się od Ameryki po Polskę.

Miasto. Pamięć i Przyszłość 1 (2016) ISSN 2543-621X 
Zauważmy. Taleb pisze o sprawach ewolucji systemów. Staje w kontrze do dwóch potężnych tradycji kształtujących życie naszych instytucji w ostatnich pokoleniach, a mianowicie do socjalizmu sowieckiego ${ }^{17}$ i socjalizmu demokratycznego, dominującego Europę w swych dwóch odmianach, tej wywodzącej się z ruchów robotniczych oraz drugiej, wywodzącej się z partii chadeckich (ludowych). Prowokując, zauważa, że obie tradycje są zbieżne w dążeniu do przesady (metoda Taleba pozwala na uogólnienia a nawet domaga się ich - byle pchać myślenie do przodu). Modele rozwojowe ludzi od dużych liczb i małej intuicji, którzy zniszczyli gospodarkę wschodniej Europy w ramach eksperymentu komunistycznego, którzy - sięgając po eufemizm - w ograniczonym stopniu pomogli Afryce pod egidą oenzetowskiej pomocy rozwojowej, którzy degenerują Europę nadregulacją i centralizacją - całe to rozległe i wielowątkowe dzieło zasługuje w opisie Taleba na jedno miano: myślenie „sowiecko-harvardzkie”18. Tym, co łączy politruka z profesorami najlepszych uczelni listy szanghajskiej, jest nadmierne dowartościowanie ludzkiej zdolności przewidywania.

Ale wspólnym substratem myśli, z którymi Taleb się mierzy, jest nie tyle jakiś model, ile racjonalna wizja świata, związana z przekonaniem o nieograniczonej mocy ludzkiego rozumu, wynikającego z antropocentryzmu, dającego człowiekowi prawo ostatecznego orzekania. I to ona jest dziś w kryzysie, którego rozmiary przewyższają wszystkie pojedyncze kryzysy europejskie, jak i inne: kryzys ONZ czy wreszcie kryzys amerykańskiej doktryny polityki zagranicznej, opartej, niezależnie od administracji, na tym samym zestawie uniwersalistycznych postulatów na temat światowej demokratycznej konwergencji w przyszłości ${ }^{19}$.

Idąc dalej, z zainteresowaniem warto odnotować, że kryzys racjonalistycznego uniwersalizmu jest odczuwalny także przez myślicieli amerykańskiej nurtu progresywnego ${ }^{20}$, mających całkiem odmienny od Taleba pogląd na rolę państwa. W 2008 r. językoznawca i badacz kognitywny George Lakoff zelektryzował elity liberalne Stanów Zjednoczonych książką, w której przedstawił wizję Nowego Oświecenia, mającego przemóc ograniczenia oświecenia pierwotnego, dając przy okazji zwycięstwo Barackowi Obamie po ośmiu latach władzy znienawidzonego G.W. Bush'a21. Teza

\section{Miasto. Pamięć i Przyszłość 1 (2016) ISSN 2543-621X}

135
17. Myśl ta jest pewnie już dziś intuicyjnie niewiarygodna. Ale prawo meldunkowe w Polsce w roku 2016 (sic!) nadal opiera się na stalinowskich założeniach.

18. op. cit., s. 9.

19. John Torode stwierdza (End of History - Or Clash of Civilisations? "Standpoint Magazine" IX 2016), że przedwcześnie zrodzona - jego zdaniem - teoria Samuela Huntingtona dziś powinna być przemyślana na nowo jako najbardziej adekwatny program dla światowej polityki. Dwadzieścia lat po publikacji Clash of Civilisations and the Remaking of World Order (New York 1997) idee amerykańskiego politologa stają się koherentne, jeśli nie w pewnym sensie prorocze, w szczególności gdy je zestawić z równoległymi ideami Francisa Fukuyamy.

20. Por. przypis 11.

21. G. Lakoff. The Political Mind. A Cognitive Scientist's Guide to Your Brain and Its Politics, New York 2008. 
Lakoffa brzmiała: partia Demokratyczna wygra wybory i obroni istotę amerykańskiej demokracji, jeżeli weźmie sobie do serca naukowe zdobycze neurolingwistyki, w szczególności dotyczące rozumowania i kojarzenia, tłumaczące (częściowo) irracjonalność ludzkich wyborów politycznych (emocje, skojarzenia i kognitywne pułapki). Progresywni (postępowi) Amerykanie muszą tak zrobić, jeżeli mają pokonać republikanów, posługujących się strachem do osiągnięcia politycznych celów²2; dzieci Wilsona muszą odrzucić staroświecką powściągliwość i wiarę w rozumnego wyborcę - bo ludzie nie są racjonalni lub są racjonalni inaczej, niżby tego chcieli zwolennicy oświeconego humanizmu²3. Na zaproszenie Nancy Pelosi, wówczas przewodniczącej Kongresu z ramienia Partii Demokratycznej, George Lakoff przemawiał do zgromadzonych delegatów tejże partii24. Możemy przyjąć, że w listopadzie 2008 wraz z liberalnym światem cieszył się ze zwycięstwa Baracka Obamy, które - jak się mogło wydawać - stanowi przełom w amerykańskiej polityce i nowy okres w polityce zagranicznej (multilateralizm), a szczególnie polityce dotyczącej Rosji (reset), jak i polityce bliskowschodniej (przypomnijmy nadzieje związane z wystąpieniem Obamy w Kairze w 2009 dwa lata przed „Arabską wiosną").

Gdzie tu kryzys? Recepta Lakoffa - przyjmując, że ją poważnie rozpatrzono, a potem zastosowano - przecież zadziałała. Otóż warto dostrzec, jak dalece niebezpieczną dla tradycji oświeceniowego racjonalizmu myśl zawiera w sobie wytłumaczenie, że w polityce „Jjastrzębie mają przewagę"25 ze względu na naturalne uposażenie ludzkiego intelektu²6. Jeżeli potrzebne jest Nowe Oświecenie, stare oświecenie jest fundamentalnie nieadekwatne, nie bierze pod uwagę podstawowej rzeczywistości ludzkiej umysłowości, nie dowartościowuje instynktu, nie potrafi znaleźć miejsca i sensu dla emocji; jest potężnym gmachem myśli filozofów, zbudowanym na lotnym piasku kaprysu mas. Zagrożenie to dostrzegł Steven Pinker27, w czambuł potępiając poglądy Lakoffa na temat języka i ludzkiej umysłowości (a publiczny spór na temat istoty języka, prowadzony przez dwóch wybitnych naukowców stanowi bądź co bądź, rzadkość nawet w dobie „gospodarki opartej na wiedzy”).

W roku 2016 hipoteza oświeceniowego uniwersalizmu - przekonanie, że światowe

22. Ibidem, s. 267-271

23. Ibidem

24. M. Cooper, Thinking of Jackasses. The grand delusions of the Democratic party, "The Atlantic" www.theatlantic.com (dostęp: 10 VIII 2016).

25. W rozdziale pt. Why Hawks Win Lakoff przedstawia wyniki badań innych naukowców, które odnosi do skuteczności politycznych narracji amerykańskiej tradycji konserwatywnej (op. cit., s. 223-229).

26. G. Lakoff, op. cit., s. 223-229.

27. S. Pinker, Block That Metaphor, "New Republic", X 2006. www. newrepublic.com (dostęp: 10 VIII 2016) cywilizacje "dorosną" do zachodniego poziomu rozwoju demokracji i praw człowieka, jeśli się im da odpowiednio dużo czasu - hipoteza ta jest zagrożona bardziej niż kiedykolwiek od XVIII w. Niekoniecznie za sprawą logiki (raczej za sprawą wstecznego

Miasto. Pamięć i Przyszłość 1 (2016) ISSN 2543-621X 
skojarzenia), ale na pewno na poważnie zwykli ludzie na Zachodzie przestają ufać swoim niezwyciężonym dotąd, nawet jeśli doświadczanym, nowoczesnym instytucjom. Przestają ufać mędrcom, którzy tymi instytucjami, spełniając sen humanistów, kierują w majestacie rozumu ${ }^{28}$.

\section{Kryzys technokratycznej polityki}

Ale co z tego wynika dla innowacji we Wrocławiu?

Zarówno próby popełnione przez Taleba, jak i wzajemne uszczypliwości Pinkera i Lakoffa dają nam interesujący pogląd na moment rozwojowy, w którym znalazł się Wrocław, aspirująca metropolia Zachodu. Jest to wiedza zachęcająca, by zadać sobie pytanie, jak dobrodziejstwa zachodniego dziedzictwa instytucjonalnego mają się do tutejszości, którą modernizujemy w dobrej wierze. Bo oświecenie, dziś obecne bodaj w siódmym-ósmym pokoleniu, którego wielkim osiągnięciem jest evidence-based policy i którego jeszcze większym przejawem jest intuicyjne (bo metodyczne) odrzucenie argumentacji nieutylitarnych, opartych na imperatywie, nakazie moralnym ${ }^{29}$ - ta właśnie kultura w Polsce istnieje tylko połowicznie. A dla zdolności innowacyjnej naszej wspólnoty kapitalne znaczenie ma to, jak tej połowiczności dokonamy - przez dopełnienie (imitację) czy też przez „coś innego” (innowację).

Nie ma wątpliwości, że o rozwoju Polski i Wrocławia mówimy już językiem rozwojowej konieczności: mówimy po angielsku, francusku i niemiecku, a rosyjskiego w tej pracy zaniechaliśmy (choć wiele słów rosyjskich opisuje znane zjawiska lepiej niż terminy zachodnie). Tyle że żaden z tych języków, symbolicznie oznaczających tutaj pewną metodę i określoną skuteczność, nie jest ojczysty. Jeśli wziąć pod uwagę kryteria, takie jak elastyczność, zdolność do stosowania zasady subsydiarności, odporność na szok zewnętrzny - najlepsze i godne naśladowania cechy administracji na Zachodzie - wrocławskie instytucje otoczenia innowacji pozostają silnie zależne od uwarunkowań znacznie odbiegających od sytuacji w USA lub Wielkiej Brytanii: od ram regulacyjnych poczynając, poprzez kulturę prawną i księgową, na dostępności prywatnego kapitału inwestycyjnego kończąc, co różni nas na tyle dużo, by znaczną część porównań odrzucić na gruncie nieadekwatności. Importowana w ramach harmonizacji prawa unijnego oraz integracji instytucjonalnej terminologia poprzedza bowiem doświadczenie, tworząc w krajowych dyskusjach problemy iście scholastyczne. Na przykład: czy w Polsce istniał problem „uniwersytetu badawczego" (research university), zanim go zaimportowaliśmy do naszej dyskusji? Zapożyczenie tego terminu otwiera

\section{Miasto. Pamięć i Przyszłość 1 (2016) ISSN 2543-621X}

137
28. Pamiętając o monumentach naszej własnej tradycji filozoficznej, warto dostrzec, że wizja „trybunału rozumu", przed który wzywał w traktach politycznych Andrzej Frycz Modrzewski swoich adwersarzy, została w tradycji evidence-based policy skonsumowana.

29. Czytelnik zauważy, że chodzić może zarówno o objawienie chrześcijańskie, którego autentyczność jest przedmiotem wiary, jak i choćby praktyki współczesnej sztuki, także tej szczególnie kontrowersyjnej, której cel trudno opisać kategoriami użyteczności. 
wprawdzie fantastyczne możliwości retorycznej komparatystyki na arenie europejskiej (gdzie wypadniemy źle), ale pomija kawał powojennej historii instytucjonalnej Polski, po dziś nieprzetrawionej, której wymownym przejawem jest stworzona komunistyczną decyzją Polska Akademia Nauk, ze swoimi 69 instytutami badawczymi rozsianymi po całym kraju. Czy lepiej zatem wprowadzać do wrocławskiego języka termin bez desygnatów, by je stworzyć w przyszłości, czy budować na tym, co już istnieje, by działać ekonomicznie, nie osuwając się w polityczną demiurgię? Może zamiast problemu "uniwersytetu badawczego" (a raczej jego braku) istniał właściwie problem inny, dziś już de facto zasłonięty przez anglosaski implant, a w rzeczywistości lepiej oddający kategorie tutejszości - problem jednorodności misji, „problem niezakotwiczenia uczelni w sprawach otoczenia”, problem małej świadomości roli „powiernictwa” w zarządzaniu szkolnictwem wyższym (niezależnie, kto jest głównym „powiernikiem” - Prawda, lokalny rynek pracy czy elity państwowe, pragnące awansu w międzynarodowych rankingach)?

Oto i my w trzeciej dekadzie demokratycznej Polski. Posługujemy się nowym językiem i nowymi procedurami (w tym „strategiami”), w znacznej mierze związanymi z akcesją do UE i wejściem w życie narzędzi polityki rozwoju regionalnego. Jak pokazuje przypadek Europejskiej Stolicy Kultury, wprawność w posługiwaniu się tym językiem jest faktem życia politycznego i ma realny wpływ na decyzje podejmowane w kręgach Komisji Europejskiej ${ }^{30}$. Z tej wprawności biorą się dziś dodatnie bilanse kasy publicznej w ko-

30. Choć możemy ubolewać nad niepotrzebnymi wyrzutami, urazami i emocjami, to dyskusja na temat ESK we Wrocławiu przynosi ciekawe spostrzeżenia w poruszanych tutaj sprawach języka, obowiązującego w europejskiej polityce publicznej. Biorąc pierwszy przykład z brzegu (list dyrektora Wydziału Kultury Urzędu Miejskiego Wrocławia Jarosława Brody opublikowany w "Gazecie Wyborczej” 2 II 2016), fraza „specyficzny język, powszechnie używany i rozumiany w Brukseli" może być w rozmowach codziennych zastępowana przez bardziej lapidarne słowo „narzecze” (http://wroclaw.wyborcza.pl/wroclaw/1,35771,19567368,dyrektor-wydzialu-kultury-w-um-ostro-odpowiada-chmielewskiemu.html, dostęp: 31 VIII 2016).

31. Jednym z największych odkryć przeglądu szkolnictwa wyższego w rozwoju Wrocławia (2011-2013), który był swoistym audytem technokratycznej szkoły myślenia o rozwoju, było „niedostateczne rozwinięcie kultury instytucjonalnej”. Obserwację tę poczynili eksperci OECD w odniesieniu do bazy faktograficznej, statystycznej, analitycznej, na podstawie której podejmowane są decyzje w szkolnictwie wyższym i administracji publicznej. W istocie: projekty unijne perspektywy 2007-2013, choć nominalnie spełniły wszelkie wymagane warunki, zakorzenione były w płytkich analizach danych regionalnych.

32. "Unfortunately, one has to admit that many East Europeans, especially the intelligentsia, have often adopted Western prejudices for themselves. It has long been the fashion of Poles, Czechs, Hungarians and Romanians to look to Paris, London, Berlin and lejnych latach budżetowych. Jednak szafując nowym pojęciem, takim jak „uniwersytet badawczy”, w znacznej mierze stwierdzamy brak występowania w rzeczywistości tego, do czego nas to pojęcie odwołuje ${ }^{31}$. Pomińmy frustrację, jaką powoduje taki stan rzeczy w zakamarkach wielu polskich dusz, być może związaną ze zjawiskiem, które Norman Davies nazwał „wzięciem za swoje zachodnich przesądów wobec siebie" ${ }^{\prime \prime 2}$. W konkretnych sytuacjach, jeśli w ogóle chcemy język zachodnich instytucji przyswoić twórczo, mamy dwie zasadnicze

Miasto. Pamięć i Przyszłość 1 (2016) ISSN 2543-621X 
opcje praktyczne. Pierwsza z nich to korekta, zmiana stanu rzeczy, tak by odpowiadał w pełni nowemu obyczajowi opisu, wraz z normami, jakie narzuca. To przyjęcie optyki "doganiania”, dominującej tak wiele rozmów o modernizacji Polski i Wrocławia. Druga to dwójmyślenie: korekta dyskursu, ale niekoniecznie świadome, intencjonalne działanie skierowane na korektę stanu rzeczy. Jest to opcja w polskiej tradycji silna; to tajna broń Polaków w walce z absurdami nowoczesności, przejawiającej się w pracy rządów, z jakimi przyszło zmagać się im od XIX w.

Pomimo wszystkiego, co się na ten temat myśli lub opowiada, polityka samorządowa we Wrocławiu pozostaje dużo bardziej intuicyjna, spontaniczna niżby na to pozwalał rygoryzm racjonalności dziś posługującej się narzędziami evidence-based policy. Jest tak na pewno dlatego, że w ogóle sprawy samorządowe ciążą ku temu, co dla społeczności jest konkretne, a to nie sprzyja nadmiernym ćwiczeniom z myślenia i ważenia to argumentów. A przy tym ciążą ku psychologicznej wiarygodności tematów, której znacznikiem jest występowanie politycznych emocji.

Ale nasza kultura instytucjonalna jest różna od niemieckiej czy francuskiej także dlatego, że polskie instytucje publiczne (wraz z uczelniami wyższymi) weszły w okres demokratyczny w pełnoobjawowym dwójmyśleniu - w orwellowskiej praktyce, polegającej na prowadzeniu racjonalnego dyskursu jako osłony dla często brutalnych, ale na co dzień zupełnie zdroworozsądkowych działań opartych na obyczaju, intuicji politycznej oraz potrzebie minimalizowania szkód.

Jedną rzeczą jest argumentować racjonalność decyzji, którą się podjęło z politycznej woli; inną rzeczą jest znieść w akcie samoograniczenia kategorię woli politycznej, jako niedostatecznie transparentną, by zrobić miejsce dla hegemona wyższego rzędu, racjonalizmu33. W dużym uproszczeniu droga, jaką Polski komunizm instytucjonalny przebył od lat powojennych do roku 1989, to droga od dogmatycznego działania do dwójmyślenia, jako koniecznej odpowiedzi na odkrywaną miałkość dogmatów. Jest to droga adaptacji, a powiem nawet - innowacji instytucjonalnej na miarę możliwości stworzonych przez daną chwilę.

Bo można uznać za przejaw adaptacji i postawy innowacyjnej kariery młodych działaczy PZPR, którzy

Miasto. Pamięć i Przyszłość 1 (2016) ISSN 2543-621X 139
New York for their models of excellence, whilst despising or ignoring their neighbours in the east. Here again west was automatically equated with best" (N. Davies. Fair Comparisons, False Contrasts: East and West in Modern European History. "Europe East and West", London 2007, s. 38).

33. Za przejaw hegemonicznego racjonalizmu, opartego na teoretycznej wierze w ludzki utylitaryzm, a ubranego tym razem w kostium demokratycznego wyzwolenia i upodmiotowienia, można uznać nurtujące w nowo powstałych ruchach miejskich oczekiwanie, że możliwie jak najwięcej decyzji politycznych będzie podejmowanych na sposób właściwy dla obywatelstwa partycypacyjnego, przez wyborców w czasie rzeczywistym bardziej niż w cyklach wyborczych. Próba taka może być widziana w istocie jako przeniesienie ośrodka władzy w inne, trudne do przewidzenia i jeszcze trudniejsze do rozliczenia z następstw własnych decyzji miejsce - o tyle, o ile element władzy w sprawowaniu władzy jest logicznie nieusuwalny. 
w latach osiemdziesiątych korzystali z przywileju podróżowania, zdobywając wiedzę na stypendiach w Stanach Zjednoczonych. Ich śmiałe obejście z zachodnimi pokusami dało później demokratycznej Polsce kompetencje, których manifestacją był jeden z niewielu poważnych planów reformy sklerotycznego państwa - Plan Hausnera ${ }^{34}$. Można za formę innowacji uznać bezkrwawą zmianę roku 1989, której istota pozostaje przedmiotem gorącego politycznego sporu, ale której stosunkowo łagodny przebieg jest powodem do dziękczynienia Bogu. Wreszcie można za interesujący przykład adaptacji innowacyjnej, pod płaszczem dwójmyślenia, wziąć ustawę Mieczysława Wilczka35 poprzedzającą wielkie zmiany. Bo jest w zjawisku dwójmyślenia marksistowsko-zdroworozsądkowego mieszanka nieznośna, przedziwna, ale i bardzo swojska, bez której trudno wyobrazić sobie dziś polskie instytucje i ich język - z jednej strony niemająca usprawiedliwienia hipokryzja; z drugiej strony godny podziwu zdrowy rozsądek, zasługujący na pochwałę kontakt z rzeczywistością (negowaną oficjalnie).

Takie są właśnie paradoksy polskiej instytucji publicznej. Od tego, jak się z nimi rozprawimy - ogniem i mieczem czy może cierpliwością i pokorą, a może inaczej zależy bardzo wiele. Możliwe, że właśnie tutaj, w doświadczeniach poniżenia i upodlenia, w dwuznacznościach i absurdach komunizmu, znajduje się klucz do odkupienia dzisiejszej polskiej polityki, do odnalezienia własnego głosu innowacji instytucjonalnej.

Jeśli strategia rozwoju Wrocławia z roku 2006 jest dziś niezmiennie użyteczna, to jest tak dlatego, że skupia się na wartościach, z których biorą się działania, usuwając w cień przygodne, instytucjonalne sposoby interwencji publicznej. Tym sposobem - i tylko tym sposobem - można zachować porządek kategorialny, dziś zagrożony pomieszaniem: „kopiowani[em] pozorów nowoczesności, a nie jej istoty, i kopiowani[em] zachowań konsumentów dobrobytu zamiast postaw jego twórców”36. Jeśli innowacyjność bierze się z przypadkowości i siły ludzkiego charakteru, rządy nowoczesnych państw mogą wprawdzie zrobić wiele, by pomóc, natomiast nie wyręczą autentycznych twórców innowacji żadną magiczną sztuczką. Logiczną konsekwencją takiego stanu rzeczy jest coś trudnego do przyjęcia na gruncie racjonalnego optymizmu, dążącego do usuwania lub skrywania ryzyka we wszystkich przejawach demokratycznego życia: swoją politykę innowacyjną władze winny zacząć od stwierdzenia swojej ostatecznej bezradności, na której dopiero mogą budować minimalny - z trwogi przed szkodami, jakich można dokonać! - program interwencji.

To jest właśnie ujęcie wrocławskiej „kultury eksperymentu” w odniesieniu do

34. Prof. Jerzy Hausner, minister w rządach Leszka Millera i Marka instytucji publicznych. Jest to kultura Belki, w latach 2003-2005 wicepremier.

35. Ustawa z dnia 23 grudnia 1988 r. o działalności gospodarczej. Dz. U. 1988 nNr 41 poz. 324.

36. Strategia..., op. cit., s. 7.

Miasto. Pamięć i Przyszłość 1 (2016) ISSN 2543-621X 
tolerująca ryzyko. I taka kultura wymaga odpowiedniego języka, uznającego ograniczenie rozumu, języka, w którym "nie wiem” nie powoduje skreślenia z grona wiedzących, ale jest formułą dającą prawo wstępu do tego grona, formułą konieczną, bo prawdziwą.

Jeśli innowacyjność jest ideą istniejącą gdzieś w świecie modeli, można ją zaprojektować. I trzeba się jej uczyć przede wszystkim na drodze rozumowej. Jeśli jest jednak umiejętnością odnajdywania się tu i teraz, klecenia nowych konceptualizacji z dostępnych odniesień, sztuka innowacji ma niekoniecznie wiele wspólnego z analizą rozumową: wymaga raczej umiejętności koncentracji, obecności, wrażliwości na fakty bezpośrednio nas dotyczące; a po naszemu powiemy: na wszystko, co odsyła nas nie w świat czystego, ale chłopskiego rozumu ${ }^{37}$. Chłopski rozum postawiony wobec terminu takiego jak research university przyznaje, że "U nas czegoś takiego nie ma”. Ale jednocześnie zna swoje strony na tyle dobrze, by dodać: „Ale jest co innego. Od tego zacznijmy".

\section{Dokąd zmierza wrocławska „kultura innowacji"? \\ Pytania na kolejne dziesięciolecie}

Wiosną 2006 w Urzędzie Miejskim doszło do serii spotkań z przedstawicielami Instytutu Immunologii PAN im. Ludwika Hirszfelda. Tłem spotkań była strategia EIT Plus, przedmiot dotyczył samego instytutu. Przy okazji jednego ze spotkań prof. Janusz Boratyński, reprezentujący instytut, choć niepełniący żadnej funkcji, pokazał urzędnikom fotografie taboru tramwajowego zrobione w zajezdni przy ul. Powstańców Śląskich. Przebieg wymiany zdań relacjonuję tak, jak ją zapamiętałem:

Prof. Boratyński: Widzi pan? Wie pan, co to jest?

Urzędnik: Tramwaj, jak sądzę.

Prof. Boratyński: Myli się pan. To jest homogenizator.

Urzędnicy: ???

Prof. Boratyński: Widzi pan, do naszych badań nad nowymi lekami potrzebujemy preparować komórki nowotworowe, które potem testujemy. Ale nie mamy pieniędzy na zakup odpowiedniego sprzętu. No więc pomyśleliśmy, że jeśliby preparat położyć na torach, i przejechać się po nim tramwajem, efekt będzie taki, jakbyśmy użyli fachowego sprzętu. Dogadaliśmy się z zajezdnią i homogenizujemy komórki, które potem wykorzystujemy w testach; wystarczy położyć na torach i najechać tramwajem.

Warto pochylić się nad tym obrazem, kończąc refleksję, której pierwszym tematem jest przejście od imitacji do innowacji oraz to, co zagraża temu przejściu - oderwaniu

Miasto. Pamięć i Przyszłość 1 (2016) ISSN 2543-621X

141
37. Zob. M. Litwin. Time, Being and Becoming: Cognitive Models of Innovation and Creation in English. Frankfurt 2015. 
od faktów, w tym faktów przyrody, w które popada rozum nadmiernie skupiony na swojej pracy, instytucja nazbyt zadowolona ze swojej podaży czy twórca zbyt zadowolony ze swojego geniuszu. Jest w tym obrazie - profesor Boratyński i jego studenci - wspaniały przykład działania rodzimego talentu, postawionego wobec ograniczenia. Jest nawet nawiązanie do narzędzia oswajania ograniczeń realnych przeszkód - do ironii i neologizmu, które dały tutaj zabawny obraz homogenizatora, choć w sytuacji bardziej nieprzyjaznej mogłyby dać monument dwójmyślenia podobny do komunistycznej „walki o pokój i demokrację”.

Dwójmyślenie jest bowiem stałym zjawiskiem kulturowym; bierze się z ekonomii języka w sytuacji presji. Nie musi kojarzyć się negatywnymi doświadczeniami, choć zostało „odkryte” w warunkach ekstremalnych dla człowieka - w komunizmie o czym w swym geniuszu wiedział George Orwell, proponując termin doublethink. Współczesne, nieinwazyjne „dwójmyślenie” wytłumaczyć można na przykładzie mniej dramatycznym. Jest to anegdotyczna rozmowa starego profesora i adiunkta:

Adiunkt: Panie profesorze, odczuwam pański dystans wobec idei wprowadzenia procedury kontroli jakości nauczania na naszym wydziale.

Profesor: Drogi kolego, skąd takie posądzenie?

A: Na każdym etapie prac słychać z pańskiej strony jedynie docinki.

P: Tak, a co ma być słychać?

A: My naprawdę chcemy dobrze; po prostu staramy się wprowadzić zmiany, na które już niemal za późno. Zachód nam coraz dalej ucieka, Chiny nas przegoniły. Musimy się modernizować.

P: Drogi kolego, po pierwsze, jeżeli jest już na coś za późno, nie ma sensu tego robić, bo jest za późno. Konkurencję wygrywa się będąc w danej kategorii pierwszym, nie ostatnim. Po drugie, ja wcale nie protestuję przeciwko temu, żeście to wszystko wprowadzili, bo ja rozumiem co to jest konieczność dziejowa. Ja tylko się boję, że wy w to wszystko uwierzycie!

Dziesięć lat po uchwaleniu strategii, dziesięć lat po rozmowie urzędnika z profesorem Boratyńskim warto się zastanowić: czy dziś prof. Boratyński mógłby zabrać studentów do zajezdni na ul. Powstańców Śląskich, by homogenizowali? Czy może potrzebowałby zgody na realizację zajęć poza instytutem, która to zgoda mogłaby wynikać z nowych procedur wprowadzonych dla podwyższenia jakości nauczania (poprzez ukrócenie samowoli pracowników naukowych)? Czy wizyta 
osób nieposiadających pisemnej zgody kierownika zajezdni byłaby zgodna z normą ISO, wprowadzaną - domniemywam - na przykład w ramach projektu unijnego z priorytetu wspierania innowacji instytucjonalnej? Czy portier, który - wyobraźmy sobie - spisał telefony i nazwiska studentów mających przyjść popracować na homogenizatorach-tramwajach powinien zarejestrować zestawienie (telefon i nazwisko) jako zbiór danych osobowych, podlegający kontroli Generalnego Inspektora Danych Osobowych? Czy motorniczy zażądałby polecenia nadgodzin, czy też wykonałby homogenizację w ramach bieżącej umowy (tutaj: czy byłby potrzebny aneks do umowy, kto zabezpieczy środki, czy sekretariat dyrektora sporządzi projekt aneksu do umowy w ramach bieżących obowiązków, nawet jeżeli homogenizowanie komórek nowotworowych nie należy do statutowych zadań MPK i dyrektor nie powinien wydawać podwładnym poleceń związanych z realizacją zadań w tym zakresie?)? Czy studenci, którzy wówczas podjęli wysiłek opuszczenia budynku Instytutu Immunologii, dziś mieliby ochotę zajmować się czymś, co nie wiadomo, jak przyda się w ich karierze, za co nie ma punktów ministerialnych, czego nie da się sensownie ująć w sprawozdaniu z działalności naukowej, do czego zachęca szalony błysk w oku niepozornego swojaka, a nie raport ekspertów, mówiących po angielsku, francusku lub niemiecku, opublikowany w recenzowanym czasopiśmie wysoko na liście filadelfijskiej?

Nie znam odpowiedzi na te pytania. Podpowiada mi je wyobraźnia instytucjonalna. Spisuję je jednak rzetelnie, by przywołać wyzwanie naszej polskiej, wrocławskiej modernizacji. Ale wierzę, że mamy jeszcze czas, aby pomyśleć o tych sprawach w nadziei na Nieoczekiwane, ale opierając się na konkretach - patrząc na tramwaje, które nie wiedzą, że mogą być homogenizatorami.

\footnotetext{
Maciej Litwin, od lutego 2015 pracownik naukowy Uniwersytetu Wrocławskiego (Instytut Filologii Angielskiej, Wydział Filologiczny). Wcześniej - współtwórca i pierwszy menedżer Wrocławskiego Centrum Akademickiego (2008-2015). Architekt miejskiej platformy współpracy naukowo-biznesowej "Mozart”. Koordynator regionalny przeglądu szkolnictwa wyższego w rozwoju Wrocławia realizowanego przez OECD w latach 2011-2013. Na Uniwersytecie Wrocławskim prowadzi badania nad mechanizmami ludzkiego myślenia ujawniajacymi się w języku (przekład) i pracuje ze studentami filologii angielskiej jako wykładowca. Wspiera analitycznie rozwiqzania polityki miejskiej zwiq̨zane ze szkolnictwem wyższym i innowacjami. Z pasją angażuje się w edukację dzieci i dorosłych.
}

\section{Miasto. Pamięć i Przyszłość 1 (2016) ISSN 2543-621X}

